American Journal of Environmental Sciences 5 (3): 278-284, 2009

ISSN 1553-345X

(C) 2009 Science Publications

\title{
Seasonal Variations of n-6: n-3 Ratios and Fatty Acid Compositions in Foot and Tissue of Chiton lamyi in a High Primary Productivity Area
}

\author{
${ }^{1}$ Nooshin Sajjadi, ${ }^{2}$ Peyman Eghtesadi-Araghi, ${ }^{1,3}$ Shahla Jamili, \\ ${ }^{2}$ Mehri Hashtroodi, ${ }^{2}$ Sahar Farzadnia and ${ }^{1}$ Ali Mashinchian \\ ${ }^{1}$ Faculty of Marine Science and Technology, \\ Islamic Azad University, Science and Research Branch, Tehran, Iran \\ ${ }^{2}$ Department of Marine Living Sciences, \\ Iranian National Center for Oceanography, Tehran, Iran \\ ${ }^{3}$ Iranian Fisheries Research Organization, Fatemi Ave, Tehran, Iran
}

\begin{abstract}
Problem statement: Fatty acid content and composition in mollusks is a function of their feeding diversity. Chabahar bay located in the northern part of Oman sea in Indian ocean provides high rates of primary productivity and a diverse food source for mollusks in this area. Identification of fatty acid compositions of Chiton lamyi and study their seasonal changes in the intertidal zone of Chabahar bay. Study the meat quality by n-6: n-3 ratios calculation throughout the year. Approach: Chiton lamyi species analyzed seasonally for its fatty acid compositions in foot and internal tissue separately by GC/MS chromatography. Temperature and nutrients measured monthly for evaluating their effects on investigated seasonal variations of fatty acids. Pearson analysis showed effects of measured environmental factors on studied fatty acids composition. n-6: n-3 ratio calculated seasonally in order to study meat quality. Results: Thirteen fatty acids identified in foot and internal tissue of Chiton lamyi. The major Saturated Fatty Acids (SFAs) were myristic, palmitic and stearic acids. The major MonoUnsaturated Fatty Acids (MUFAs) were palmitoleic, oleic and 11-eicosenoic acids and PolyUnsaturated Fatty Acids (PUFAs) were linoleic, eicosapentaenoic and arachidonic acids. Palmitic acid was the most abundant in this species. Fatty acid contents of foot and internal tissue of Chiton lamyi were similar but their seasonal variations were different. Pearson analysis showed correlation among palmitic and oleic acids with silicate; oleic acid with phosphate; Linoleic and arachidonic acids with nitrate in Chiton lamyi internal tissues, but no correlation observed in foot. Although temperature showed correlation with heptadecanoic and methyl-heptadecanoic acids in Chiton lamyi foot, no correlation found in internal tissues. Also, n-6: $n-3$ ratio calculations showed domination of $n-3$ fatty acid over n-6 only in spring. Conclusion: Fatty acid variations were not same at different organs and environmental factors could have opposite effects on them in this species. Also, n-6: n-3 ratio showed the lack of food loads throughout the year except in spring for this species. These findings can lead the best exploitation periods for such marine mollusks.
\end{abstract}

Key words: Fatty acids, Chiton lamyi, GC/MS, environmental parameters

\section{INTRODUCTION}

Fatty acids in marine invertebrates are studied in many habitats because of their importance in human's life $^{[1]}$. One of these studies has been carried out by Ackman and Joseph ${ }^{[2,3]}$ in a large number of mollusks.

The phylum Mollusca has a great importance because of their fatty acid components and their variability in different areas ${ }^{[4]}$.

One of the important classes of this Phylum is polyplacophora, which their feeding ecology and gut contents analysis have been studied by Latyshev ${ }^{[5]}$ and distribution of major fatty acids in Ponerplax costata (polyplacophora) was reported before ${ }^{[6]}$.

The effects of environmental factors on the fatty acids have been studied insufficient, however thermo tropic behavior of major phospholipids in marine invertebrates were studied ${ }^{[7]}$ and seasonal variations of fatty acids were followed by Abad in flat oysters ${ }^{[8]}$.

Chabahar bay is located along the coast of Sistan province in the south east of Iran, northern part of Oman Sea in Indian Ocean. Seasonal upwelling due to

Corresponding Author: Peyman Eghtesadi-Araghi, Department of Marine Living Sciences,

Iranian National Center for Oceanography, Tehran, Iran Tel: +982166944873 Fax: +982166944869 
monsoonal currents in this area generate one of the highest rates of primary productivity in the world ${ }^{[9,10]}$. This phenomenon provides a diverse and unique dietary selection for mollusks, which in turn might result in different compositions of fatty acids. There is no previous report about fatty acid compositions of mollusks in this region. This study deals with fatty acid compositions quantitatively and their seasonal variations in whole internal body tissue and foot of a polyplacophora Chiton lamyi for the first time. Thereafter the relation of seasonal fatty acid variations with environmental factors such as temperature and nutrients (phosphate, nitrate and silicate) studied. Also, n-6: n-3 ratio is one of the important factors which show energy consumption from the food sources or unsaturated fatty acids by the species. So this process could be affected by seasonal changes, which leads to $n-6: n-3$ ratio variations and is studied in this research too.

\section{MATERIALS AND METHODS}

Adult Chiton lamyi collected with the same size in four seasons at April, July, October 2007 and February 2008). About 30 Chiton were collected from rocky shores in every sampling at Chabahar bay, with northern $60^{\circ} 37^{\prime} 45^{\prime \prime}$ longitude and $27^{\circ} 15^{\prime} 45^{\prime \prime}$ latitude between two stations at the distance of about $7 \mathrm{~km}$, where the water depth is $3-3.5 \mathrm{~m}$. Temperature and nutrients were measured monthly in the collecting site at the same time. After sampling, the species transferred to the lab immediately. Foot and whole tissue dissected from the species, weighed and froze to $-18^{\circ} \mathrm{C}$ for further experiments. Afterward extraction was carried out by using a homogenizer (Wagtech T1813) for species tissues with a solvent mixture of chloroform/methanol 2:1 (v/v) and volume to weight ratio 20:1 (v/w). About $50 \mathrm{ppm}$ of BHT ( Butylated Hydroxy Toluene) added as an antioxidant for prevent of unsaturated fatty acids oxidation $^{[11]}$. The total extract filtered under vacuum using glass fiber filter (whatman, S and S, GF6) and then $0.25 \mathrm{~g} \mathrm{NaCl}$ added for more efficiency of extraction. The aqueous layer re-extracted with chloroform. Combined organic layer volume reduced to 3-5 $\mathrm{mL}$ by rotary evaporator. Hydrolyze of fatty acids with $5 \%$ aqueous $\mathrm{KOH}$ (20 and methanol $(100 \mathrm{~mL})$ carried out for $2-3 \mathrm{~h}$ at reflux temperature. After cooling, distilled water $(50 \mathrm{~mL})$ added and the basic solution extracted twice with n-heptane/diethyl ether 1:1 (v/v). The aqueous methanolic layer was acidified to $\mathrm{pH}=2$ and fatty acids extracted for three times with
$50 \mathrm{~mL}$ of $\mathrm{n}$-heptane/diethyl ether $1: 1(\mathrm{v} / \mathrm{v})$ and dried with anhydrous $\mathrm{MgSO}_{4}$, filtered and the filtrate reduced to $2-3 \mathrm{~mL}^{[6]}$. The fatty acids esterified with solution of $14 \% \mathrm{BF}_{3}$-methanol ${ }^{[12]}$ and heated in boiling water for $5 \mathrm{~min}$. After cooling, $1 \mathrm{~mL}$ water and $2 \mathrm{~mL}$ pentane added to the sample, vortexed (Stuart SA8) for $1 \mathrm{~min}$ and then centrifuged (Heraeus Biofuge) and upper phase collected. Pentane was evaporated and the residue dissolved immediately in 50-100 $\mu \mathrm{L}$ n-hexane. This solution was ready for injection to the gas chromatograph. Each sample was treated and analyzed for triplicates.

Separation of FAMES was performed by a GC/Mass apparatus made up by Agilent Technologies (6890) with a mass selective detector $(6973 \mathrm{~N})$.

GC/Mass analysis was done with electron impact (EI) mode of $70 \mathrm{ev}$ as ionization source and quadrupole mass filter with Chemstation data analysis system. The capillary column used was HP-5 (5\% diphenyl 95\% dimethyl silloxane copolymer) with $30 \mathrm{~m}$ length, $320 \mu \mathrm{m}$ internal decimeter and $1 \mu \mathrm{m}$ film thickness.

Carrier gas was helium (purity 99.999\%). $0.5 \mu \mathrm{L}$ of extract containing fatty acids methyl esters was injected in the injector using split mode with 50:1 split ratio. Injector temperature was $200^{\circ} \mathrm{C}$, detector temperature was $280^{\circ} \mathrm{C}$, oven temperature programmed from $75^{\circ} \mathrm{C} \mathrm{min}{ }^{-1}$ to $270^{\circ} \mathrm{C}$ at $30^{\circ} \mathrm{C} \mathrm{min}^{-1}$ and the final temperature held for $20 \mathrm{~min}$ in replicated test runs to insure that all the components detected ${ }^{[13]}$.

The fatty acid methyl esters identified by comparing the obtained peaks with the chromatograms of commercial fatty acid standards. The Pearson correlation coefficients were applied for study the relationships among the fatty acids variations and environmental parameters.

In addition, regression analysis used for the components, which resulted strong correlations in Pearson analysis, in order to predict effectiveness of each environmental factor as independent variable, on fatty acids as dependent.

\section{RESULTS}

The seasonal variations of temperature and nutrients are shown in Fig. 1 (from June 2007 until March 2008). As shown in Fig. 1a, water temperature had a minimum of $21^{\circ} \mathrm{C}$ in February and reached to its maximum $\left(33^{\circ} \mathrm{C}\right)$ in July. Silicate and phosphate had slightly similar trend, reached to their maximum levels in summer (Fig. 1b and c), as 0.6 and $0.50 \mathrm{ppm}$ respectively. Nitrate (Fig. 1d) reached to its maximum $(2.81 \mathrm{ppm})$ in May and had its minimum $(0.05 \mathrm{ppm})$ in April. 
Am. J. Environ. Sci., 5 (3): 278-284, 2009

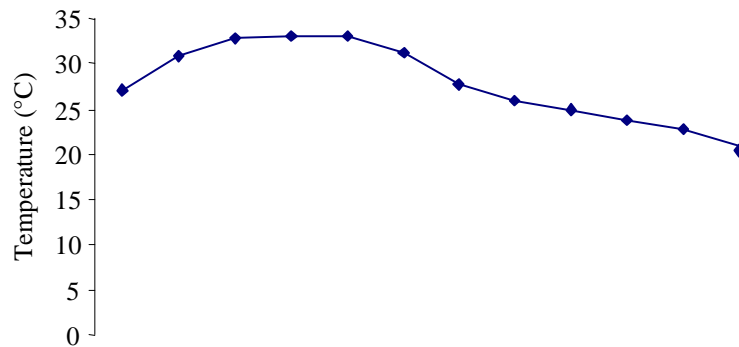

(a)

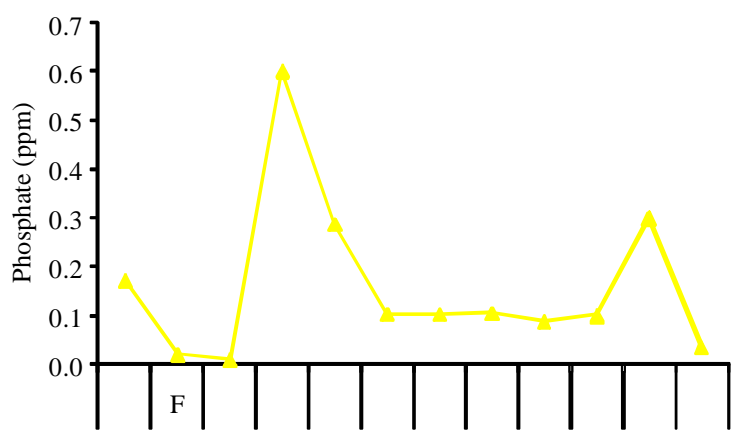

(c)

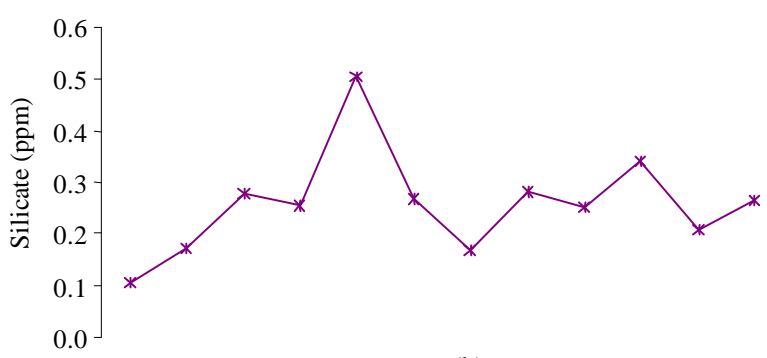

(b)

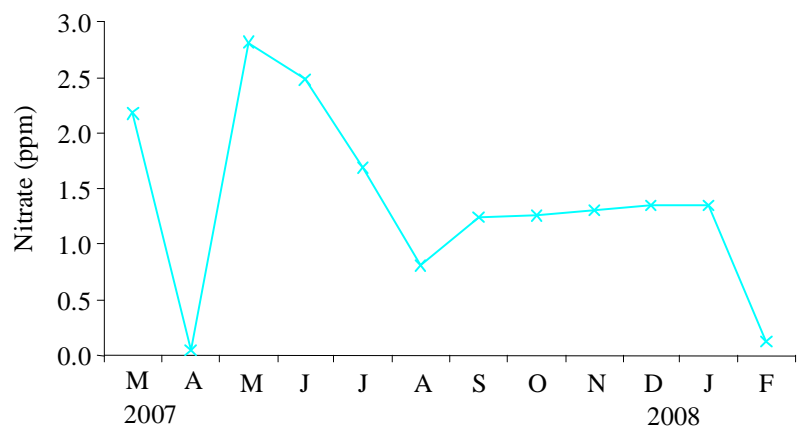

(d)

Fig. 1: Variations of environmental parameters in four seasons at Chabahar bay

Table 1: Fatty acid contents in internal tissues of Chiton lamyi

\begin{tabular}{lrrrr}
\hline Fatty acids & \multicolumn{1}{c}{$\begin{array}{l}\text { Spring } \\
(\%)\end{array}$} & \multicolumn{1}{c}{$\begin{array}{l}\text { Summer } \\
(\%)\end{array}$} & \multicolumn{1}{c}{$\begin{array}{c}\text { Fall } \\
(\%)\end{array}$} & \multicolumn{1}{c}{$\begin{array}{l}\text { Winter } \\
(\%)\end{array}$} \\
\hline $14: 0$ & 4.691 & 3.751 & 0.409 & 4.977 \\
$4,8,12$-tri Me-13:0 & 13.560 & 5.733 & 1.683 & 6.589 \\
$15: 0$ & 4.783 & 3.455 & 2.487 & 4.335 \\
$16: 1 \mathrm{n}-9$ & 2.166 & 2.401 & 3.271 & 5.185 \\
$16: 0$ & 25.050 & 39.051 & 32.185 & 31.677 \\
$17: 0$ & 2.269 & 3.018 & 3.505 & 2.418 \\
Me-17:0 & 2.466 & 2.725 & 5.175 & 3.364 \\
$9,12-18: 2$ & 5.597 & 10.261 & 11.446 & 9.379 \\
$18: 1 \mathrm{n}-9$ & 18.255 & 9.646 & 17.284 & 15.060 \\
$18: 0$ & 5.408 & 6.099 & 7.953 & 5.185 \\
$20: 4 \mathrm{n}-6$ & 3.353 & 5.146 & 4.691 & 4.707 \\
$20: 5 \mathrm{n}-3$ & 6.666 & 2.890 & 4.327 & 2.386 \\
$20: 1 \mathrm{n}-11$ & 5.737 & 5.823 & 5.586 & 4.739 \\
Total saturated $(\%)$ & 58.227 & 63.832 & 53.397 & 58.545 \\
Total unsaturated $(\%)$ & 41.774 & 36.167 & 46.605 & 41.456 \\
\hline
\end{tabular}

Table 1 shows thirteen fatty acids identified in internal body tissue of Chiton lamyi, including seven saturated and six unsaturated, which the major saturated ones were myristic, palmitic and stearic acids. The monoenoics were palmitoleic, oleic and dodecanoic (n11) fatty acids. In the dienoic group of fatty acids, only linoleic acid identified. Arachidonic acid and eicosapentaenoic acid (EPA) were identified as polyenoic acids .Palmitic acid was the major saturated (varied from minimum $25.05 \%$ in spring to maximum $39.05 \%$ in summer) and oleic acid was the major unsaturated one (varied from minimum of $9.64 \%$ in summer to maximum $18.25 \%$ in spring).
Table 2: Total fatty acid contents in Chiton lamyi foot

\begin{tabular}{lrrrr}
\hline Fatty acids & \multicolumn{1}{c}{$\begin{array}{l}\text { Spring } \\
(\%)\end{array}$} & $\begin{array}{l}\text { Summer } \\
(\%)\end{array}$ & \multicolumn{1}{c}{$\begin{array}{l}\text { Fall } \\
(\%)\end{array}$} & \multicolumn{1}{c}{$\begin{array}{l}\text { Winter } \\
(\%)\end{array}$} \\
\hline $14: 0$ & 9.972 & 9.503 & 9.432 & 2.735 \\
$4,8,12$-tri Me-13:0 & 0.794 & 1.156 & 1.101 & 1.189 \\
$15: 0$ & 3.480 & 3.807 & 4.673 & 3.126 \\
$16: 1 n-9$ & 9.573 & 10.874 & 9.723 & 4.103 \\
$16: 0$ & 33.990 & 36.085 & 38.528 & 27.448 \\
$17: 0$ & 0.898 & 0.753 & 1.315 & 1.757 \\
Me-17:0 & 1.378 & 1.260 & 2.347 & 3.483 \\
$9,12-18: 2$ & 12.662 & 14.434 & 14.211 & 10.363 \\
$18: 1 n-9$ & 19.119 & 16.116 & 12.808 & 25.760 \\
$18: 0$ & 3.168 & 1.103 & 2.251 & 4.861 \\
$20: 4$ n-6 & 0.958 & 1.636 & 0.700 & 5.114 \\
$20: 5 n-3$ & 1.811 & 1.539 & 0.538 & 3.280 \\
20:1n-11 & 2.196 & 1.733 & 2.372 & 6.783 \\
Total saturated $(\%)$ & 53.680 & 53.667 & 59.647 & 44.599 \\
Total unsaturated $(\%)$ & 46.319 & 46.332 & 40.352 & 55.403 \\
\hline
\end{tabular}

The proportion of saturated fatty acids varied from $53.39-63.83 \%$ of total lipids in internal body tissue of Chiton lamyi that dominated over unsaturated fatty acids (36.16-46.60\%). The maximum level of saturated fatty acids was in summer and for the unsaturated ones was in fall. Peaks $<0.2 \%$ of the total area and fatty acids have not being founded in all four seasons were not included in the profiles.

Fatty acid components found in Chiton lamyi foot were the same as its internal tissue (Table 2). Similarly, palmitic acid was the major saturated fatty acid (varied from $27.44 \%$ in winter to $38.52 \%$ in fall) and oleic acid was the major unsaturated one (varied from $12.80 \%$ in 
fall to $25.76 \%$ in winter). Saturated fatty acids (varied from 44.59-59.64\%) were most abundant than unsaturated ones, which varied from 40.35-55.40\%. The maximum level of saturated fatty acids observed in fall and for the unsaturated fatty acids was in winter. Consequently, there was not a similarity in the results of the percentages amounts of total saturated and unsaturated fatty acids in internal tissue and foot of Chiton lamyi during the experiment period.

Seasonal variations of saturated fatty acids in internal tissue and foot of Chiton lamyi are shown in Fig. 2. According to Fig. 2a, fatty acids including 17:0, 18:0 and Me17:0 had a similar variation trend in internal tissue of Chiton lamyi, their maximum level was in fall and minimum observed in spring. Also tri Me-13:0 and 15:0 fatty acids had a similar seasonal variation trend, their maximum level was in spring and minimum occurred in fall.

In Fig. 2b, 15:0 and 16:0 fatty acids varied similar to each other in Chiton lamyi foot, reached to their maximum and minimum levels in winter and summer, respectively. 17:0, 18:0 and Me17:0 fatty acids had a similar seasonal variation in Fig. $2 b$, which could be a common point with Fig. 2a, but the difference was in their maximum and minimum levels, which occurred respectively in winter and summer in Chiton lamyi foot.

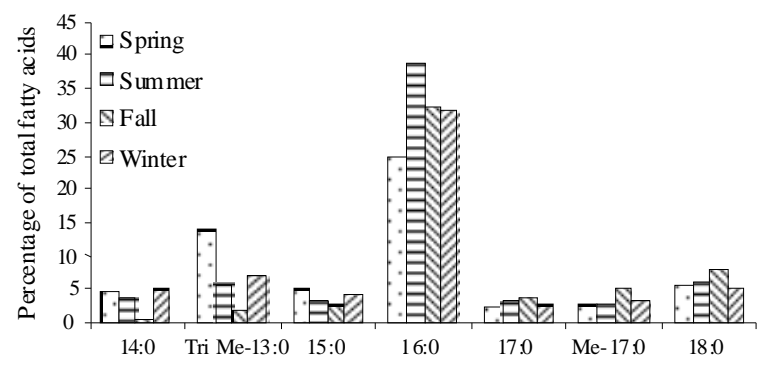

(a)

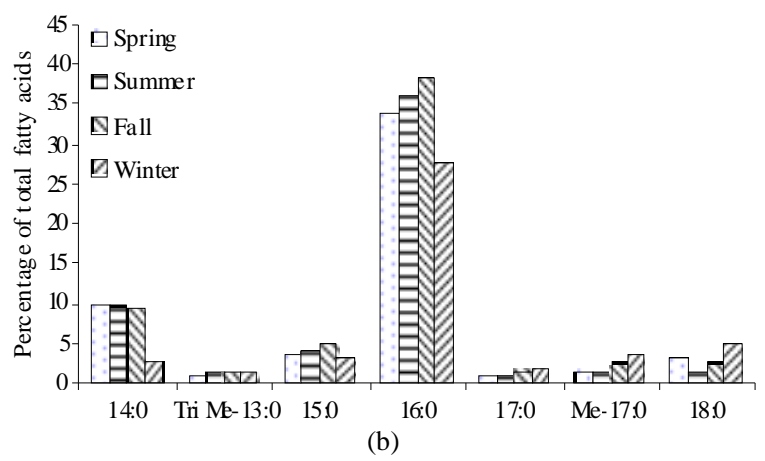

Fig. 2: Seasonal variations of saturated fatty acids of Chiton lamyi (a): Internal tissues; (b): Foot
Figure 3 shows compared seasonal variation trends of unsaturated fatty acids in internal body tissue and foot of Chiton lamyi. Oleic and eicosapentaenoic acids varied similar to each other in internal tissue of Chiton lamyi (Fig. 3a), reached to their maximum level in spring and their minimum level was in summer. Due to Fig. 3b, linoleic and palmitoleic acids had a similar variation trend throughout the year in Chiton lamyi foot, reached to their maximum and minimum levels in summer and winter respectively. Oleic and eicosapentaenoic acids varied similar to each other in Chiton lamyi foot, which coincides with Fig. 3a, but the maximum and minimum levels was in summer and winter and this similar trend for this two fatty acids could be another common point for seasonal variations of fatty acids in internal tissue and foot of Chiton lamyi.

The n-6: n-3 ratio was measured seasonally and was $0.50,1.78,1.08$ and 1.97 in internal tissue and $0.53,1.06,1.30$ and 1.56 in foot of Chiton lamyi.

In order to obtain any relation between seasonal variations of fatty acids and environmental parameters (temperature, silicate, phosphate and nitrate), Pearson correlation applied for both internal body tissue and foot of Chiton lamyi. Correlation coefficient matrix for temperature and thirteen fatty acids of Chiton lamyi foot, showed strong negative correlation between 17:0 and Me17:0 fatty acids and temperature $(r=-0.99$ and-0.98) which indicates that by increase temperature the amount of these fatty acids will decrease.

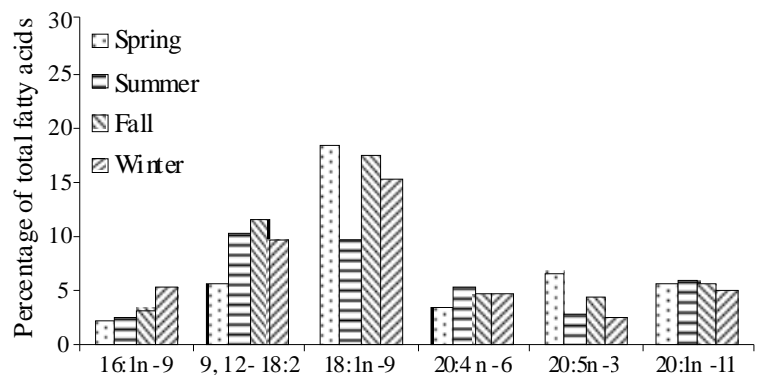

(a)

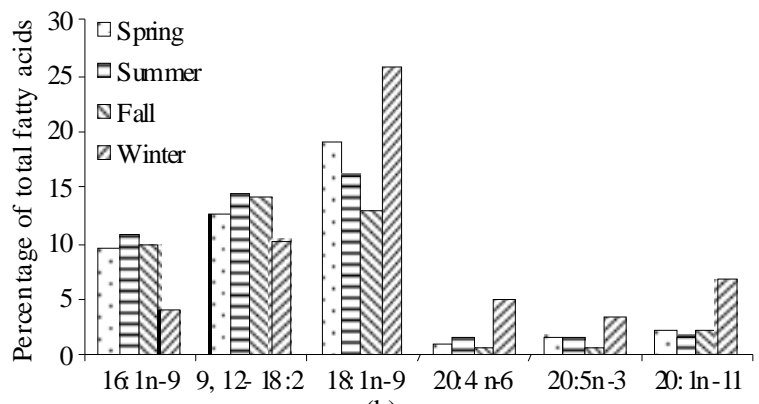

(b)

Fig. 3: Seasonal variations of unsaturated fatty acids of Chiton lamyi (a): Internal tissues; (b): Foot 
Am. J. Environ. Sci., 5 (3): 278-284, 2009

Table 3: Regression analysis for temperature and me 17:0 Fatty acid Unstandardized coefficients Standardized

\begin{tabular}{lllllll} 
& & & & & & \\
Model & & B & Std. error & Beta & \multicolumn{1}{l}{ t } & Sig. \\
\hline 1 & (Constant) & 0.092 & 0.011 & & 8.691 & 0.013 \\
& Temperature & -0.003 & 0.000 & -0.979 & -6.739 & 0.021 \\
\hline
\end{tabular}

Dependent variable: Me 17:0 Fatty acid; $\mathrm{r}^{2}=0.95$

Table 4: Regression analysis for temperature and 17:0 Fatty acid

\begin{tabular}{|c|c|c|c|c|c|c|}
\hline \multirow[b]{2}{*}{ Model } & & \multicolumn{2}{|c|}{$\begin{array}{l}\text { Unstandardized } \\
\text { coefficients }\end{array}$} & \multirow{2}{*}{$\begin{array}{l}\text { Standardized } \\
\text { coefficients } \\
\text { Beta }\end{array}$} & \multirow{2}{*}{$\mathrm{t}$} & \multirow[b]{2}{*}{ Sig. } \\
\hline & & B & Std. error & & & \\
\hline \multirow[t]{2}{*}{1} & (Constant) & 0.043 & 0.002 & & 17.377 & 0.003 \\
\hline & Temperature & -0.001 & 0.000 & -0.994 & -12.727 & 0.006 \\
\hline
\end{tabular}

Pearson analysis had not any significant coefficient for other fatty acids of Chiton lamyi foot with temperature and for fatty acids of the internal body tissue of Chiton lamyi with this parameter either. Due to significant coefficients for17:0 and Me17:0 fatty acids and temperature, univariate regression analysis was applied by considering temperature as independent variable and each fatty acid as dependent and gave $r^{2}$ equals with 0.98 and 0.95 and implies strong effect of temperature on the amounts of mentioned fatty acids (Table 3 and 4). According to Table 3 and 4, future amounts of these fatty acids are predictable by applying regression equation as follows:

$\mathrm{Y}=\mathrm{a}+\mathrm{b} 1 \times 1+\mathrm{b} 2 \times 2+\mathrm{b} 3 \times 3+\ldots$

Where:

$\mathrm{Y}=$ The unstandardized coefficient (amount of fatty acid), parameter a is constant and is derived from the Table 3 and 4

$\mathrm{b}=$ Efficiency coefficient and is calculated in the Table 3 and 4 either and $\mathrm{x}$ will be the measured value for temperature

At a similar pattern, Pearson analysis performed for the nutrients and the fatty acids of internal body tissue and foot of Chiton lamyi. There was not found any primary result for the seasonal variations of fatty acids and each nutrient's seasonal change for the foot samples and correlations were not significant in the resultant matrix. Secondary results derived from analyzing the amounts of each nutrients seasonal change with the percentages of seasonal variations in fatty acids for internal body tissue of Chiton lamyi. Resulting matrixes showed significant correlations for nitrate with linoleic $(r=-0.980)$ and arachidonic $(\mathrm{r}=-0.96)$ acids; silicate with palmitic $(\mathrm{r}=0.95)$ and oleic $(\mathrm{r}=-96)$ acids and phosphate with oleic acid $(\mathrm{r}=-0.96)$. Considering the obtained $r$-values, univariate regression analyses applied. From r2 values for linoleic (0.96) and arachidonic (0.93) acids as dependent variables and regression analysis, prediction the effectiveness of nitrate as independent variable could be possible as mentioned above (equation1). At the same way, $\mathrm{r}^{2}$ for palmitic $(0.90)$ and oleic $(0.98)$ was derived in relation to silicate. $\mathrm{R}^{2}$ value for phosphate and oleic acid was 0.93.Considering oleic acid as the common component for phosphate and silicate in Pearson analysis, bivariate regression analysis done for oleic acid as dependent in relation to phosphate and silicate as independent variables. This analysis had not a significant value. Therefore, it is possible to conclude that each environmental parameter could have an individual effectiveness on the fatty acids, but in the case of applying a series of parameters simultaneously, the outcome will be ineffective.

\section{DISCUSSION}

The fatty acid components of internal body tissue of Chiton lamyi are as same as Chiton lamyi foot, but their percentages amounts are different. The variability in fatty acids amounts in different organs of other mollusks studied before ${ }^{[14]}$. In the case of Chiton lamyi, there is some dissimilarity in fatty acid amounts in internal body tissue and the foot. This difference may be explained with the point of different physiological adaptation of organs that remain exposed to ecological surroundings that produce different amounts and varied types of fatty acids. Among the saturated fatty acids, the major fatty acid was palmitic acid (C16:0) in both samples. This coordinates with previous reports ${ }^{[1,15]}$, that palmitic acid is the main fatty acid in mollusks and in all trophic levels too. In addition to palmitic acid, other major fatty acids were myristic (in foot) and stearic (in internal body tissue). The amount of $4,8,12$ tri methyl-13:0 fatty acid was observed more abundant in internal body tissue of Chiton lamyi, with a maximum level in spring. 4, 8, 12 trimethyl tridecanoic acid (4, 8, 12 TMTD) origins from the herbivore chiton's diet and is derived from phytol and chloroplast membrane lipids ${ }^{[16,17]}$. So it is possible that internal organs contribute in the metabolism of this fatty acid, more than foot. Although in other reports ${ }^{[15,18]}$ predomination of unsaturated fatty acids was observed, It is found that in this mollusk saturated fatty acids were most abundant than the unsaturated ones. The reason could be related to the fact that fatty acid compositions and their seasonal variations of mollusks or other invertebrates, is affected by a sequence of environmental and biological factors in each habitat. 
The maximum level of unsaturated fatty acids in Chiton lamyi foot was observed in winter, while in internal body tissue was in fall. Other researchers ${ }^{[19,20]}$ had reported an inverse relationship between temperature and the amount of polyunsaturated fatty acids in tissue lipids of invertebrates, due to the adaptive regulation of melting point of cellular lipids. It should be noted the difference in the case of internal tissue and foot of Chiton lamyi in this founding, is possibly due to the adaptation of different organs to climatic conditions, such as temperature changes.

Seasonal variations of fatty acids such as 17:0, Me17:0 and 18:0 had similar trends through the research period in internal tissue of Chiton lamyi. This result observed in Chiton lamyi foot either. In the case of unsaturated ones oleic and eicosapentaenoic fatty acids had similar seasonal variation trend in foot and the same result obtained in internal tissues. Therefore, it is clear that not all fatty acid components have a similar pattern for variation throughout a year, neither in an individual tissue nor between different organs.

The n-6: n-3 ratio is less than one only in spring and indicates a good source of food which could be algae and microalgae for this species. Although in other seasons the n-6: $n-3$ ratio is more than one and shows there is a lack of food loads which leads the species to intake the energy storages of unsaturated fatty acids. On the other hand since the species need more energy levels in reproduction cycles, it could be concluded these periods are from summer to end of fall in Chiton lamyi, which increase the consumption of unsaturated fatty acids as energy sources.

Two important environmental factors altering tissue lipid levels of invertebrates are temperature and nutrients (food availability). This, together, maybe contributed to seasonal variations in fatty acid compositions of Chiton lamyi. Looking for this purpose Pearson analysis was done for fatty acids in relation to temperature and nutrients (silicate, phosphate and nitrate) as environmental factors. Components which showed correlation with temperature were 17:0 and Me17:0 fatty acids, only in foot. Therefore, temperature could have further effects in fatty acids of the organs more exposed to external environmental conditions depending on the structure and physiology of those organs. In the case of nutrients they had correlations with a few fatty acids of internal tissues and for the Chiton lamyi foot, there was not observed any correlation. The reason is perhaps for the role of these nutrients in metabolism of internal organs more than foot. Lombardi and Parrish ${ }^{[21,22]}$ investigated accumulation of total lipids in phytoplankton cells under nutrient (silicon, phosphorus and nitrogen) depletion. Also according to other researches ${ }^{[23]}$, mineral limitation of aquatic herbivores, appear frequently to be limited by the quantity of mineral elements in their food. Therefore, it is possible that nutrients effect directly in fatty acid contents of mollusks due to their feeding regime.

Since little published reports exists on lipids of chitons, especially for the species of Chabahar bay area, this research would be of value for other researchers that are interested in this field.

\section{CONCLUSION}

Consequently, it should be emphasized that fatty acid contents of internal body tissue and foot of Chiton lamyi are similar, but there is a difference between fatty acid variation trends for these organs in different seasons. Therefore, it could be observe that fatty acid variations are not the same at different organs of a mollusk. Among ecological factors, temperature and nutrients were studied in relation to fatty acids that resulted in internal tissues and foot of Chiton lamyi opposite to each other. Some fatty acids had relation with temperature in foot, but some of them being affected by nutrients in internal tissues. Considering obtained results, generally we could conclude that there is not an absolute existing relation between temperature or nutrients and fatty acids variations in this species. Besides other factors such as chlorophyll-a, food supply or internal factors same as reproduction cycle could also affect.

\section{ACKNOWLEDGEMENT}

This research was a part of first researchers $\mathrm{PhD}$ Thesis. The researchers thank Iranian National Centre for Oceanography (INCO) that funded the project with resources received from corresponding author grant number 385-0111.

\section{REFERENCES}

1. Ackman, R.G., 2000. Fatty Acids in Fish and Shellfish. In: Fatty Acids in Foods and their Health Implications, Chow, C.K. (Ed.). M. Dekker, Inc., CRC Press, New York and Basel, ISBN: 9780849372612, pp: 153-172.

2. Ackman, R.G., J.L. Sebedio and M.I.P. Kovacs, 1980. Role of eicosenoinc and docosenoic fatty acids in fresh water and marine lipids. Mar. Chem. 9: 157-167. DOI: 10.1016/0304-4203(80)90034-1 
3. Joseph, J.D., 1989. Distribution and Composition of Lipids in Marine Invertebrates. In: Marine Biogenic Lipids, Fats and Oils, Ackman, R.G. (Ed.). CRC Press, Boca Raton, FL., ISBN: 9780849348891, pp: 472.

4. Dembitsky, V.M., T. Rezanka and A.G. Kashin, 1994. Comparative study of the endemic freshwater fauna of lake Baikal-IV, phospholipid and fatty acid compositions of two gastropod molluses of the genus Valvata. Comparat. Biochem. Physiol., 107: 325-330. http://cat.inist.fr/?aModele $=$ afficheN\&cpsidt $=3916923$

5. Latyshev, N.A., 2004. A study on the feeding ecology of chiton using analysis of gut contents and fatty acid markers. J. Mulasc. Stud., 70: 225-230. http://mollus.oxfordjournals.org/cgi/content/abstrac $\mathrm{t} / 70 / 3 / 225$

6. Johns, R.B., P.D. Nichols and G.J. Perry, 1980. Fatty acid components of nine species of molluscs of the littoral zone from Australian waters. Comparat. Biochem. Physiol. Part B., 65: 207-214. http://dx.doi.org/10.1016/0305-0491(80)90004-8

7. Sanina, N.M. and E.Y. Kostetsky, 2002. Thermotropic behaviour of major phospholipids from marine invertebrates: Changes with warmacclimation and seasonal acclimatization. Comparat. Biochem. Physiol. Part B., 133: 143-153. DOI: 10.1016/S1096-4959(02)00092-1

8. Abad, M., C. Ruiz, D. Martinez, G. Mosquera and J.L. Sanchez, 1995. Seasonal variations of lipid class and fatty acids in flat oyster, Ostrea edulis, from San Cibran, (Galicia, Spain). Comparat. Biochem. Physiol., 110: 109-118. http://dx.doi.org/10.1016/0742-8413(95)00006-A

9. Passow, U., R. Peinert and B. Zeitzsche, 1993. Distribution and sedimentation of organic matter during the inter-monsoon period off Oman (West Arabian Sea). Deep Sea Res. Part 2: Top. Stud. Oceanogr., 40: 833-849. DOI: 10.1016/09670645(93)90061-Q

10. Barlow, R.G., R.F.C. Mantoura and D.G. Cummings, 1999. Monsoonal influence on the distribution of phytoplankton pigments in the Arabian Sea. Deep Sea Res. Part 2: Top. Stud. Oceanogr., 46: 677-699. http://dx.doi.org/10.1016/S0967-0645(98)00123-4

11. Jones, I.D., L.S. Buttler, E. Gibbs and R.C. White, 1972. An evaluation of reversed phase partition for thin-layer chromatographic identification of chlorophylls and derivatives. J. Chromat., 70: 87-98. http://dx.doi.org/10.1016/S0021-9673(01)91061-1

12. Morrison, W.R. and L.M. Smith, 1964. Preparation of fatty acid methyl esters and dimethylacetals from lipids with boron fluoride-methanol. J. Lipid Res., 5: 600-608. http://www.jlr.org/cgi/content/abstract/5/4/600
13. Casado, A.G., E.J.A. Hernandez, P.E. Espinoza and J.L. Vilchez, 1998. Determination of total fatty acids (C8-C22) in sludge by gas chromatography-mass spectrometry. J. Chromatogr. Part A., 826: 49-56. http://dx.doi.org/10.1016/S0021-9673(98)00725-0

14. Misra, K.K., I. Shkrob, S. Rakshit and V.M. Dembitsky, 2002. Variability in fatty acids and fatty aldehydes in different organs of two prosobranch gastropod molluscs. J. Biochem. Syst. Ecol., 30: 749-776. http://dx.doi.org/10.1016/S0305-1978(01)00150-8

15. Fuentes, A., I. Fernandez-Segovia, I. Escriche and J.A. Serra, 2009. Comparison of physico-chemical parameters and composition of mussels (Mytilus galloprovincialis Lmk.) from different Spanish origins. Food Chem., 112: 295-302. http://dx.doi.org/10.1016/j.foodchem.2008.05.064

16. Wood, B.J.B., 1974. Fatty Acids and Saponifiable Lipids. In: Algal Physiology and Biochemistry, Stewart, W.D.P. (Ed.). University of California Press, USA., ISBN: 10: 0520024109.

17. Johns, R.B., P.D. Nichols and G.J. Perry, 1979. Fatty acid composition of ten marine algae from Australian waters. Phytochemistry, 18: 799-802. http://dx.doi.org/10.1016/0031-9422(79)80018-7

18. Freites, L., U. Labata and M.J. Fernandez-Reiriz, 2002. Evolution of fatty acid profiles of subtidal and rocky shore mussel seed (Mytilius galloprovincialis, LmK.). Influence of environmental parameters. J. Exp. Mar. Biol. Ecol., 268: 185-204. http://dx.doi.org/10.1016/S0022-0981(01)00377-X

19. Chu, F.L.E. and J. Greaves, 1991. Metabolism of palmitic, linoleic and linolenic acids in adult oysters, Crassostrea virginica. Mar. Biol., 110: 229-236. http://dx.doi.org/10.1007/BF01313708

20. Pazos, A.J., C. Ruiz, O. Garcia-Martin, M. Abad and J.L. Sanchez, 1996. Seasonal variations of the lipid content and fatty acid composition of Crassostrea gigas cultured in El Grove, Galicia, NW Spain. Comparat. Biochem. Physiol., 114: 171-179. http://dx.doi.org/10.1016/0305-0491(96)00017-X

21. Lombardi, A.T. and P.J. Wangersky, 1991. Influence of phosphorus and silicon on lipid class production by the marine diatom Chaetoceros gracilis grown in turbidostat cage cultures. Mar. Ecol. Prog. Ser., 77: 39-47. http://www.int-res.com/articles/meps/77/m077p039.pdf

22. Parrish, C.C. and P.J. Wangersky, 1990. Growth and lipid class, composition of the marine diatom, Chaetoceros gracilis, in laboratory and mass culture turbidostats. J. Plankt. Res., 12: 1011-1021. http://plankt.oxfordjournals.org/cgi/citmgr?gca=pla nkt; $12 / 5 / 1011$

23. Sterner, R.W. and D.O. Hessen, 1994. Algal nutrient limitation and the Nutrition of Aquatic Herbivores. Annu. Rev. Ecol. Syst., 25: 1-29. DOI: 10.1146/annurev.es.25.110194.000245 